\title{
Vulnerability assessment of seawater intrusion and effect of artificial recharge in Pondicherry coastal region using GIS
}

\author{
V. Lenin Kalyana Sundaram ${ }^{* 1}$, G.Dinesh ${ }^{2}$, G.Ravikumar ${ }^{3}$ and D.Govindarajalu ${ }^{4}$ \\ ${ }^{* 1}$ Centre for Water Resources, CEG, Anna University, Chennai - 600 025, India. \\ ${ }^{2}$ Department of Ocean Engineering, Indian Institute of Technology, Chennai - 600036. \\ ${ }^{3}$ Department of Chemical Engineering, A. C. Tech, Anna University, Chennai - 600025. \\ ${ }^{4}$ Department of Civil Engineering, Pondicherry Engineering College, Pondicherry - 605014. \\ lenin_1979@yahoo.com*
}

\begin{abstract}
An Indicator based model is described to assess and quantify the significance of vulnerability to seawater intrusion due to excessive ground water withdrawals: also to analyze the impact of artificial recharge in minimizing the seawater intrusion for coastal aquifers. Thematic maps of factors influencing the seawater intrusion and artificial recharge were prepared and overlaid using Geographical Information System (GIS). Based on GALDIT Index, the aquifer vulnerability index mapping was carried out. The distributions of the vulnerability areas for good, moderate and poor class are $32 \%, 45 \%$ and $23 \%$ respectively. These maps can be used as a tool for management of the coastal ground water resources. Further, the vulnerable areas are reclassified into two zones: good and poor potential areas (recharge zones). The influence of artificial recharge in pushing the freshwater-seawater interface towards the sea was simulated. For different options of surface water availability and artificial recharge, the possibility of remedial measures of seawater intrusion is
\end{abstract} estimated.

Keywords: Aquifer vulnerability mapping, Sea water intrusion, GALDIT Index, Artificial recharge, GIS, Overlay.

Introduction

Coastal aquifers constitute an important source of fresh water supply but are often confronted with the problem of seawater intrusion. In coastal plains, due to inadequate storage facilities, most of the rainwater flows towards sea as runoff. Population growth, agricultural, industrial and domestic requirements exploit the available ground water with decreasing recharge areas. Regulation of ground water extraction is essential to optimize the overdraft, reducing the risk of seawater intrusion. The entire seawater intrusion phenomenon is governed by Ghyben-Herzberg relation (Todd, 1980). The lighter fresh water lies over the seawater and the boundary surface between them is known as the freshwaterseawater interface. This distribution was attributed to a hydrostatic equilibrium existing between the two fluids of different densities. For each meter of fresh ground water found above sea level, $40 \mathrm{~m}$ of freshwater exists below sea level at that point. When drawdown occurs, the base of the freshwater lens is adjusted at a rate of $40 \mathrm{~m}$ for each meter of drawdown in the well through upconing effect.

Artificial recharge is one of the remedial measures to minimise seawater intrusion in coastal alluviums. Modern tools such as Geographical Information System (GIS) can be extensively used in ground water investigations and analysis for mapping purposes, based on the compiled database (vector or raster). GIS is used to delineate areas favorable for recharge both in hard rock and sedimentary environs and to recommend suitable recharge structures. Different thematic maps, such as geology, geomorphology, soil, land use, etc., were prepared from maps, toposheets, and overlaid with suitable ranks and weights (Saraf \& Choudhury,1998; Ramalingam \& Santhakumar, 1999). It is also used to analyse the hydrogeological data for the assessment of ground water condition of a soft rock terrain in Midnapur district, West Bengal, India (Shahid \& Nath, 2000), in Gurgaon District, Haryana, India (Toleti et al., 2000), in Raniganj area (Sikdar et al., 2004). Phukon et al. (2004) applied multicriteria evaluation technique in GIS environment for ground water resource mapping in Guwahati city areas. GIS and SCS-CN model has been applied to estimate the runoff potential from the entire study area (Das et al., 1992, Manivannan et al., 2001, Nayak et al., 2003, Kulkarni et al., 2004, Solaimani et al., 2005, Benedict Mutua \& Andreas Klik, 2006). Identification of favourable recharge zones and adapted site-specific artificial recharge techniques based on the hydrogeomorphic approach in Bhatsa and Kalu river basins is carried out using GIS (Zade et al., 2005).

In this study, an attempt is made to estimate runoff potential for the study area using SCS-CN method in GIS environment, to delineate the area extent of seawater intrusion by preparing a vulnerability map, to identify the areas favourable for artificial recharge by integrating various thematic maps and to simulate the effect of artificial recharge on the sea water intrusion. 
Fig. 1. Index map of study area

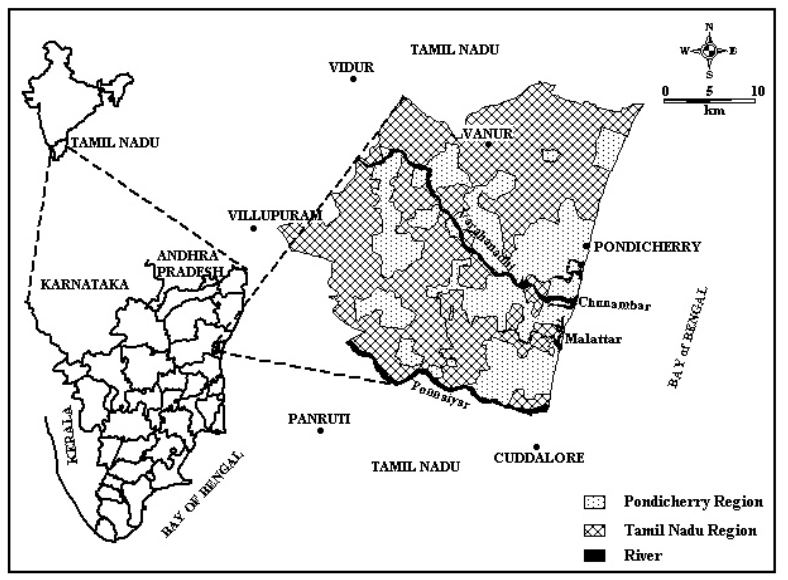

Study area

The study area, Pondicherry Coastal Region, spreads over $840 \mathrm{~km}^{2}$ including the Pondicherry Union Territory with an area of $297.5 \mathrm{~km}^{2}$, bounded between latitudes $11^{\circ} 45^{\prime} \mathrm{N}$ and $12^{\circ} 05^{\prime} \mathrm{N}$ and longitudes $79^{\circ} 31^{\prime} \mathrm{E}$ and $79^{\circ} 5^{\prime} \mathrm{E}$. The region is impounded with Bay of Bengal on the East, Ponnaiyar River in the South and Kaluvezhi Swamp in the North. Also it comprises, part of Cuddalore and Villupuram districts of Tamil Nadu State. Agriculture farms are the major economic activity of the rural population. Paddy is a major crop raised in the region throughout the year. The study area map is depicted in Fig. 1.

Except for a meagre part of the North-eastern corner of the region, the entire area is covered by sedimentary formations ranging in age from cretaceous to recent. The oldest sedimentary formations are the cretaceous sediment of Mesozoic era and they are exposed in the Northwestern part of the region and North of Varahanadhi. The Palaeocene formation of Lower Tertiary is represented by the Kadapperikuppam and Manaveli formations. The recent (quaternary) formations in the region are represented by laterites and alluvium. Laterite occurs as thin cap over the Cuddalore formations. Thick alluvial deposits are built up along the course of Ponnaiyar and Varahanadhi rivers covering three fourths of the region. It occurs in the inter-stream area and also in the North of Varahanadhi river in the area extending from Pondicherry town on the East to Usteri tank on the West. The alluvium is composed of sand, clay, silt, gravel and kankar. The thickness of alluvium varies from 10 to $55 \mathrm{~m}$ in various places. The region is a flat plain with an average elevation of $15 \mathrm{~m}$ above M.S.L. The terrain becomes a little undulating with prominent high grounds varying from 30 to $45 \mathrm{~m}$ above M.S.L towards interior Northwest and North-eastern part of the region. http://www.indjst.org

Vol.1 No 7 (Dec. 2008)

\section{Methodology}

The methodology is explained in the steps of (i) Aquifer vulnerability mapping, (ii) Identification of areas favourable for artificial recharge and (iii) simulating the effect of artificial recharge (using runoff from rainfall) on seawater intrusion.

Aquifer vulnerability mapping

Chachadi et al. (2003) has proposed a method for aquifer vulnerability mapping. The most important mapable factors that influence sea water intrusion are identified as follows:

(i) Ground water occurrence (aquifer type; unconfined, confined and semi confined);

(ii) Aquifer hydraulic conductivity;

(iii) Level of ground water above sea;

(iv) Distance from the shore (distance inland perpendicular from the shoreline);

(v) Impact of existing status of sea water intrusion in the area;

(vi) Thickness of the aquifer being mapped.

A numerical ranking system has been devised using the above factors to assess sea water intrusion extent. The system contains three significant parts: weights, ranges and ratings. Each factor has been evaluated with respect to the other factors to determine the relative importance of each factor by assigning a relative weight.

The fifth factor, namely the status of seawater intrusion in the study area is studied through the mapping of spatial variation of $\mathrm{Cl} /(\mathrm{CO} 3+\mathrm{HCO} 3)$ ratio. Parameters that are normally used for seawater intrusion analysis are $\mathrm{Ca} / \mathrm{Mg}$, Total alkalinity/Total hardness, $\mathrm{Cl} /\left(\mathrm{Co}_{3}+\mathrm{HCO}_{3}\right)$ ratios, Chloride content, Electrical conductivity (EC) etc. In this study, the $\mathrm{Cl} /\left(\mathrm{CO}_{3}+\mathrm{HCO}_{3}\right)$ ratio is used to delineate the interface. Chloride is most dominant in ocean water and normally occurs in small amounts in ground water, while $\mathrm{HCO}_{3}$ is usually the most abundant negative ion in ground water but it occurs in minor amounts in the seawater. The $\mathrm{Cl} /(\mathrm{CO} 3+\mathrm{HCO} 3)$ ratio is calculated for all the wells and these point values are taken to prepare the spatial variation map using the neighbourhood interpolation technique. Similarly, the other factors are evaluated and used. From these, the GALDIT (Combining the first letters of the above significant factors) Index is calculated as:

GALDIT Index $=\left(W_{1} \times G\right)+\left(W_{2} \times A\right)+\left(W_{3} \times L\right)+$ $\left(\mathrm{W}_{4} \times \mathrm{D}\right)+\left(\mathrm{W}_{5} \times \mathrm{I}\right)+\left(\mathrm{W}_{6} \times \mathrm{T}\right)$

Where, $W_{1}$ to $W_{6}$ are the relative weights assigned to the six factors. The ratings of for all the factors were assigned by reclassifying the influencing factors with different ranges through a trial and error method. In this study, the ranges and weightages were modified to suit to the study area (Aller et al., 1987, Chachadi et al., 2003). The 
Indian Journal of Science and Technology $\quad$ Vol.1 No 7 (Dec. 2008)

ranges and weightages used for the vulnerability

granular zone suitable for percolation. In hard rock mapping is presented in Table 1.

terrain, the surface water percolation depends on

Table 1. Modified ratings and weightages for the GALDIT Index estimation

\begin{tabular}{|l|c|c|c|c|c|c|}
\hline \multicolumn{1}{|c|}{ Theme/ ratings } & 1 & 3 & 5 & 7 & 9 & Weightage \\
\hline $\begin{array}{l}\text { Ground water } \\
\text { occurrence }\end{array}$ & Confined & $\begin{array}{c}\text { Leaky } \\
\text { confined }\end{array}$ & Unconfined & & 1 \\
\hline $\begin{array}{l}\text { Aquifer hydraulic } \\
\text { conductivity (m/day) }\end{array}$ & $<3$ & $3-8$ & $8-15$ & $15-30$ & $>30$ & 2 \\
\hline $\begin{array}{l}\text { Level of ground water } \\
\text { above sea (m) }\end{array}$ & $>10$ & $10-0$ & $0-(-5)$ & $(-5)-(-10)$ & $<-10$ & 5 \\
\hline $\begin{array}{l}\text { Distance from the shore } \\
\text { (km) }\end{array}$ & $>20$ & $20-12$ & $12-7$ & $7-3$ & $<3$ & 3 \\
\hline $\begin{array}{l}\text { Impact of existing } \\
\text { status of sea water } \\
\text { intrusion (Chlorine } \\
\text { bicarbonate ratio) }\end{array}$ & $<0.25$ & $0.25-0.5$ & $0.5-1$ & $1-1.5$ & $>1.5$ & 6 \\
\hline $\begin{array}{l}\text { Thickness of aquifer } \\
\text { being mapped (m) }\end{array}$ & $>25$ & $25-15$ & $15-10$ & $10-5$ & $<5$ & 3 \\
\hline
\end{tabular}

Table 2. Criterion table for identifying artificial recharge zones

\begin{tabular}{|c|c|c|c|c|c|}
\hline \multirow{2}{*}{ Theme } & Rank1 & Rank2 & Rank3 & Rank4 & \multirow{2}{*}{ Weightage } \\
\hline & $4 *$ weightage & $3^{*}$ weightage & $2 *$ weightage & $1 *$ weightage & \\
\hline Geology & Alluvium & $\begin{array}{l}\text { Shally sandstone, } \\
\text { shell limestone }\end{array}$ & $\begin{array}{l}\text { Weathered } \\
\text { Charnockite }\end{array}$ & $\begin{array}{l}\text { Shale and } \\
\text { calcareous } \\
\text { Sandstone with } \\
\text { clay. }\end{array}$ & 15 \\
\hline Geomorphology & $\begin{array}{l}\text { Flood plain, } \\
\text { Alluvial plain, } \\
\text { Coastal plain, } \\
\text { Beach sand }\end{array}$ & $\begin{array}{l}\text { Shallow buried } \\
\text { pediment, Pediment }\end{array}$ & $\begin{array}{l}\text { Deep buried } \\
\text { pediment }\end{array}$ & $\begin{array}{l}\text { Sedimentary } \\
\text { High Ground, } \\
\text { High Ground }\end{array}$ & 30 \\
\hline $\begin{array}{l}\text { Hydrological soil } \\
\text { group }\end{array}$ & Class A & Class B & Class C & Class D & 20 \\
\hline Runoff & Low & Less moderate & Moderate & High & 10 \\
\hline Surface slope & $\begin{array}{l}\text { Normally } \\
\text { level }\end{array}$ & Very slightly sloping & $\begin{array}{l}\text { Slightly } \\
\text { sloping }\end{array}$ & $\begin{array}{l}\text { Moderately } \\
\text { sloping }\end{array}$ & 10 \\
\hline Land use & $\begin{array}{l}\text { Sandy, mud } \\
\text { flat, Water } \\
\text { bodies }\end{array}$ & $\begin{array}{l}\text { Fallow, Land with or } \\
\text { without scrub, wet } \\
\text { crop, Village } \\
\text { settlements }\end{array}$ & $\begin{array}{l}\text { Agricultural } \\
\text { plantations, } \\
\text { Dry crop }\end{array}$ & $\begin{array}{l}\text { Urban } \\
\text { settlements, } \\
\text { Gullied ravine, } \\
\text { salt affected }\end{array}$ & 15 \\
\hline
\end{tabular}

The vulnerability classes were divided with four equal ranges of GALDIT index values and designated as severe, moderate, mild and very mild vulnerable areas.

Identification of areas favourable for artificial recharge

Artificial recharge is depends on the local topographic, geological and soil conditions. The basic requirements are the maximum percolation rate and sustenance of the recharged water in the aquifer. In consolidated formation, it needs the presence of unsaturated/partially saturated or top

the presence of weathered or highly fractured rock system with appreciable thickness of unsaturated layer at the top.

The main component of runoff potential available in different regions of the study area is estimated using Soil Conservation Service (SCS) method of US Department of Agriculture as available in National Engineering Handbook (Mockus, 1972). The land use and soil maps are prepared and overlaid to get a new theme with attributes of both in GIS environment. Curve Number (CN) and antecedent moisture condition 
(AMC II) values for various combinations of the soil and land use are derived from the $\mathrm{CN}$ table (Mockus, 1972). Using query analysis, the observed values of $\mathrm{CN}$ are transferred to the newly derived theme map using Maplnfo Software. Generally the runoff depth varies for the same CN of different areas, because it depends on total rainfall of the region. The average runoff potential for the study area was determined from the daily rainfall data of $75 \%$ dependable rainfall year. Using this rainfall, separate runoff values were calculated for each polygon. The average runoff potential depth for the study area is $329.4 \mathrm{~mm}$ for $75 \%$ dependable rainfall year. Based on the runoff values, the runoff potential of the whole region is reclassified into high, moderate, less moderate and low. It is used as a main input in identifying the areas for artificial recharge. Identifying the artificial recharge zones is carried out using "weighted overlay analysis method" (Stoertz and Bradbury, 1989). The various thematic maps are given suitable weightages and ranks based on the relative importance. Suitable sites were selected by integrating the maps with their corresponding weighted index. Finally, while integrating the thematic maps, the respective weightages and ranks are multiplied to get the integrated value for each polygon. Then it is reclassified into groups such as Good, Moderate and Poor. In this study, the weightages are derived from Saraf \& Choudhury, 1998 and Ramalingam \& Santhakumar, 1999 for the study area and is adopted. The criterion table with suitable ranks and weightages adopted in this study is presented in Table 2.

Simulation of effect of artificial recharge on seawater intrusion

As the intrusion of sea water contaminates both the freshwater and the aquifer, the location of the interface is important in the development of ground water resources. Any increase of freshwater level above the sea level, through artificial recharge, will increase the depth of fresh water at that point and will push the interface towards sea. This will reclaim the inbetween areas after artificial recharge. The shifting of interface can be studied using the ground water flow rate equation (Bear, 1972, see Raudkivi \& Callander, 1976) as below.

$\mathrm{Q}_{\mathrm{o}} \mathrm{L}+\frac{\mathrm{PL}^{2}}{2}=\frac{\mathrm{K}_{\mathrm{f}}}{2}\left(\frac{\Delta \gamma}{\gamma_{\mathrm{f}}}\right)\left(\frac{\gamma_{\mathrm{s}}}{\gamma_{\mathrm{f}}}\right) \mathrm{Z}_{\mathrm{o}}^{2}$
Where,

$Q_{0} \quad$ - Discharge necessary to ensure that seawater does not intrude beyond specified limit $\left(\mathrm{m}^{3} / \mathrm{s} / \mathrm{m}\right)$

L - Length of seawater intrusion ( $m$ )

$\mathrm{P}$ - Recharge (m/s)

$\mathrm{K}_{\mathrm{f}}$ - Hydraulic conductivity with respect to freshwater $(\mathrm{m} / \mathrm{s})$

$\gamma_{\mathrm{S}} \quad$ - Weight density of seawater $\left(\mathrm{N} / \mathrm{m}^{3}\right)$

$\gamma_{\mathrm{f}} \quad$ - Weight density of freshwater $\left(\mathrm{N} / \mathrm{m}^{3}\right)$

$\Delta \gamma=\gamma_{\mathrm{s}}-\gamma_{\mathrm{f}}\left(\mathrm{N} / \mathrm{m}^{3}\right)$

$\mathrm{Z}_{\mathrm{O}}$ - Seawater peizometric head $(\mathrm{m})$

\section{Results and discussion}

Southwest monsoon rainfall occurs from June to September and Northeast monsoon rainfall occurs during October to December. There are three major soil groups available in the region. The percentage distributions of the soil classes B, C and $D$ are $55.5 \%, 8.3 \%$ and $36.2 \%$ respectively. This shows that the most of the soils are suitable for Paddy and Sugarcane crops. Land use data indicates that agricultural land, gullied ravines and salt affected land, built-up land and water bodies are $68 \%, 9 \%, 12 \%$ and $11 \%$ respectively.

Based on the $\mathrm{Cl} /(\mathrm{CO} 3+\mathrm{HCO} 3)$ ratio, the spatial variation is reclassified into five classes as shown in Fig. 2. It shows that the quality is very poor in Southern part near Cuddalore and in the interior part near Vanur. This may be due to the low hydraulic conductivity and long term stagnation of ground water in the aquifer. The runoff potential

\section{Fig. 2. Map showing the impact status of seawater intrusion}

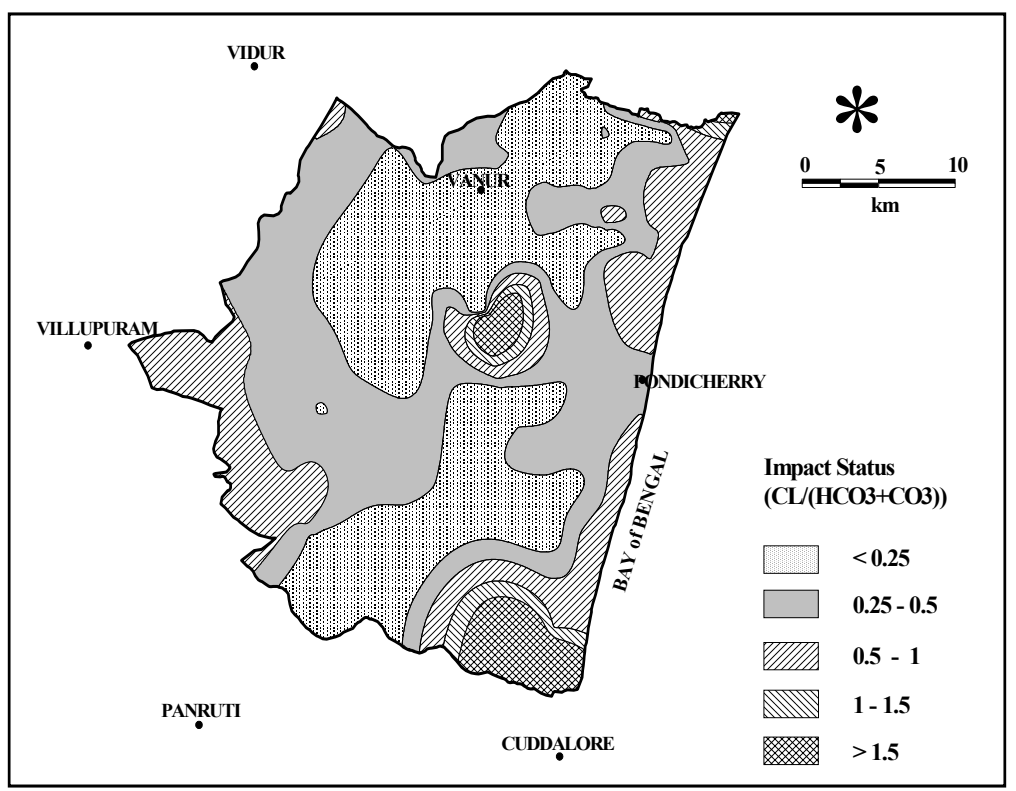


Indian Journal of Science and Technology

Fig. 3. Runoff potential map

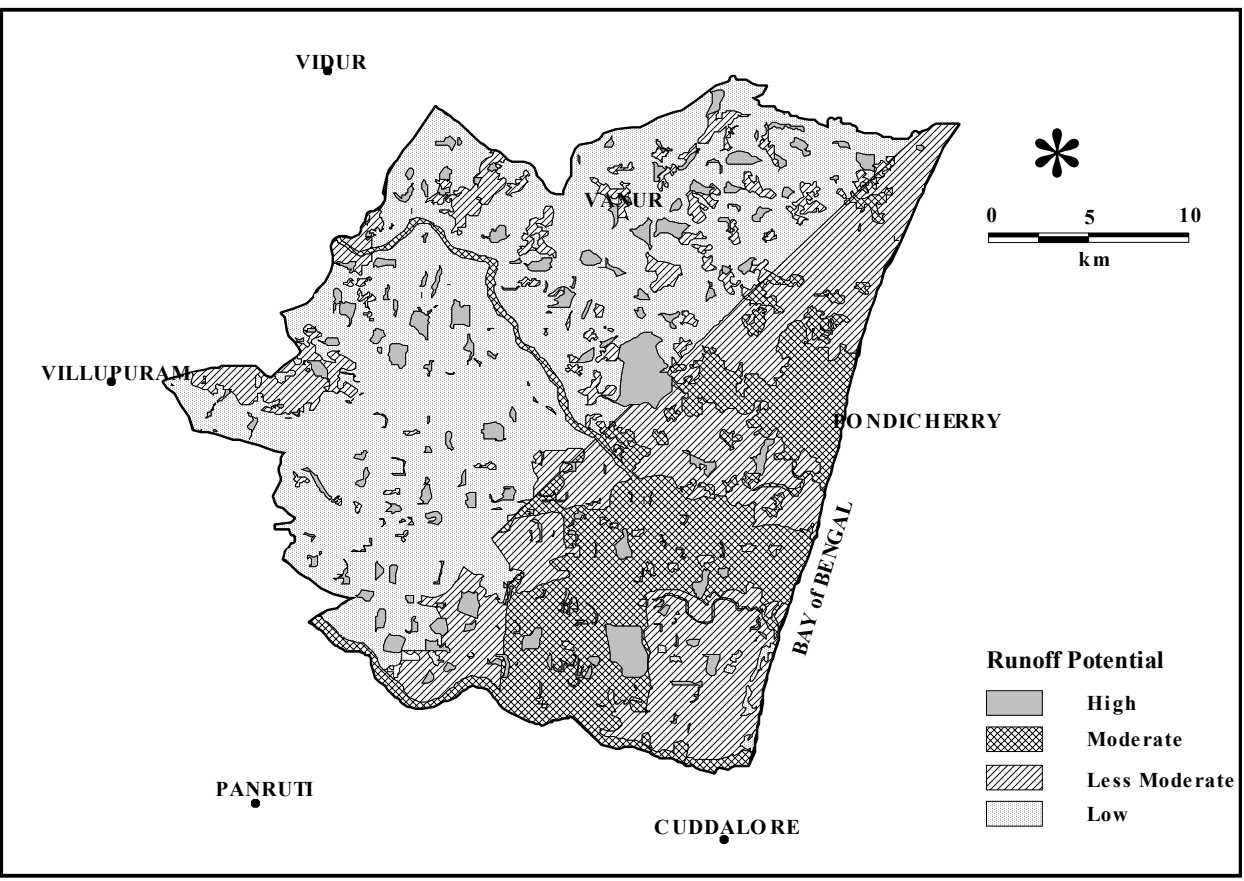

map derived using SCS-CN method is presented in Fig. 3.

The six most influencing factors of seawater intrusion explained earlier were prepared individually and are given the ratings as per Table 1. Once the rating was given, each layer is assigned a weightage based on their rank. Using ArcView GIS software, the layers are overlaid one over the other taking two at a time. Thus the final overlaid map is prepared and it contains the characteristics of all the above mentioned parameters. Final GALDIT index values are obtained by adding values of each influencing parameter for each region. With the input of all the six influential factors, GALDIT index was estimated and found to have a minimum value of 22 and maximum value of 180 . Reclassification of the final map using the GALDIT index gives a final vulnerability map and is presented in Figure 4. Even though the Pondicherry town is a densely populated area, most of the domestic demand is supplied through distribution networks by municipality. But there are heavy pumping is carried out for agricultural and industrial purposes in rest of the coastal areas. This might be the reason for which the length of seawater intrusion near to seawater intrusion http://www.indjst.org

Vol.1 No 7 (Dec. 2008)
Pondicherry town is less compared to rest of the coast The regions that are severely vulnerable to seawater intrusion are reclassified into two zones namely Zone A and Zone B. Zone A represents the seawater intrusion that may occur about 12 $\mathrm{km}$ from the sea shore. Zone B represents the seawater intrusion that may occur about $9 \mathrm{~km}$ from the seashore. Also it is seen from the vulnerability map that the Northeast area has a small pocket of region just below Vanur with a high

The maps of geomorphology, hydrological soil group, runoff, surface slope and land use are generated with their corresponding attributes. Further, the rankings and weightages for each layer are assigned and each theme is overlaid to get the final map with attributes. Based on the values of ratings and weightages, The recharge potential has been classified into three categories as good, moderate and poor where the index Fig. 4. Map showing the areas vulnerable

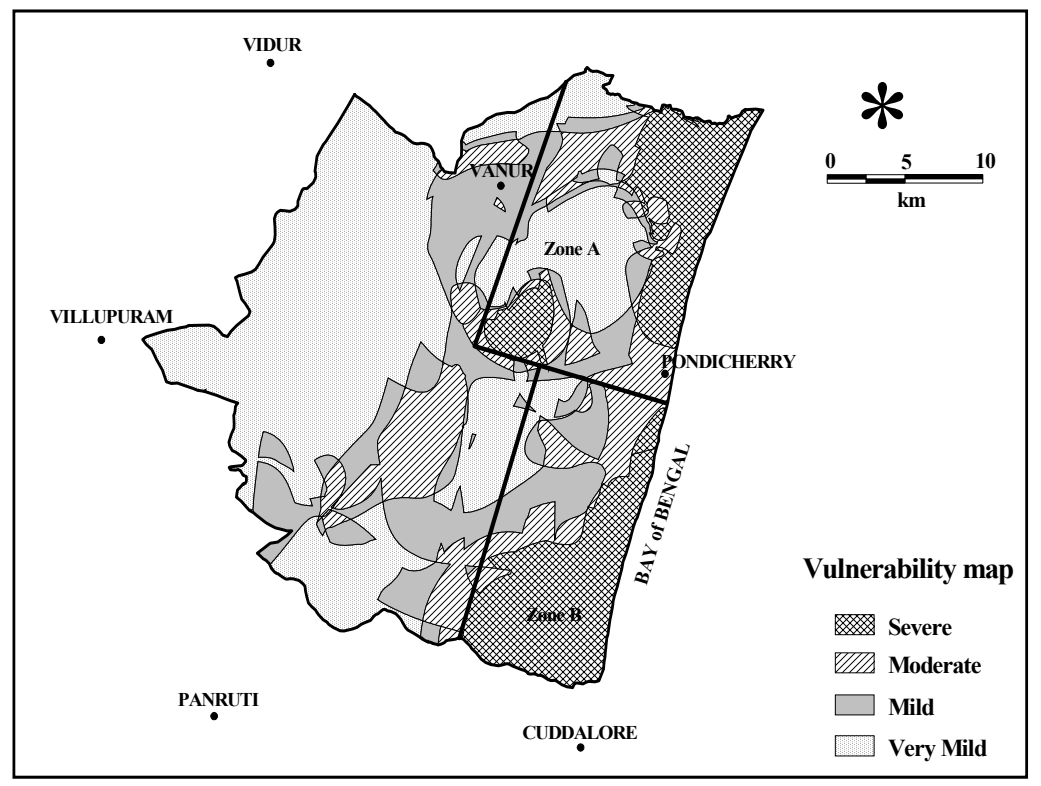


values ranges between 315 to 380,260 to 315 and below 260 respectively. The percentage distribution of areas for each category is $13 \%, 13 \%$ and $74 \%$ for good, moderate and poor respectively. Fig. 5 shows the suitable areas for artificial recharge.

Fig. 5. Classification of areas favourable for artificial recharge
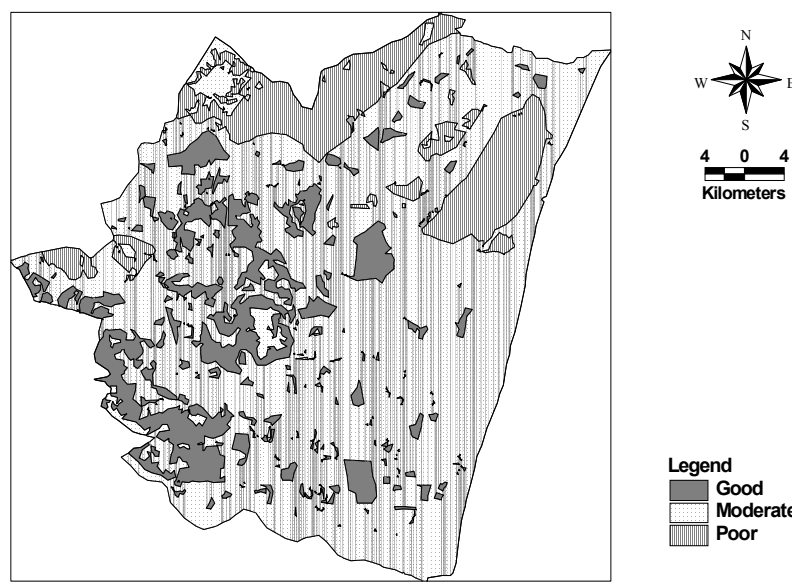

Simulating the effect of artificial recharge on seawater intrusion

The quantity of water that has to be recharged for pushing the interface towards sea is simulated by taking the factors such as, length of seawater intrusion, amount of recharge, density of seawater and freshwater, hydraulic conductivity of freshwater and peizometric head of seawater. The quantum of water required for recharge to decrease the length of intrusion to a distance of $5,4,3,2,1$ and $0.1 \mathrm{~km}$ from the sea are simulated for both the Zones (Table 3 ). It is inferred that Zone $B$ needs more quantity to be recharged than Zone $A$. The hydraulic conductivity for Zone B is higher than that of Zone A. Higher the conductivity, faster will be the movement of seawater. The estimated quantity of runoff is distributed among the various regions based on their favourability for recharge. The total rechargeable quantity may be distributed as 50 ,

Table 3 Quantity of water required to be recharged on the aquifer

\begin{tabular}{|c|c|c|}
\hline $\begin{array}{c}\text { Distance } \\
\text { from sea } \\
(\mathrm{km})\end{array}$ & \multicolumn{2}{|c|}{$\begin{array}{c}\text { Quantity required to be recharged } \\
\text { (MMC/year) }\end{array}$} \\
\cline { 2 - 3 } & Zone A & Zone B \\
\hline 5 & 14.12 & 38.79 \\
\hline 4 & 20.17 & 60.60 \\
\hline 3 & 30.26 & 96.97 \\
\hline 2 & 50.43 & 169.70 \\
\hline 1 & 110.94 & 387.88 \\
\hline 0.1 & 1200.14 & 4315.15 \\
\hline
\end{tabular}

iSee(c) category: Research article

Indian Society for Education and Environment
35 and $15 \%$ for good, moderate and poor recharge areas respectively for better management practices. The total quantity of water to be recharged artificially to push the intrusion towards sea from its present location for Zone A and Zone $\mathrm{B}$ are presented in Table 4.

Conclusion

The vulnerability map of Pondicherry region has been derived to show the impact of seawater intrusion along the coastal zone. South-western side of the study area near Ponnaiyar river and mouth of the creeks (near Ariyankuppam river and Malatar) are affected by seawater intrusion. The study has evident that the runoff potential has scope for artificial recharge towards minimising the seawater intrusion. The identified zones of good and moderate areas for artificial recharge can be utilised to increase the ground water potential which will serve as a better way to minimize/prevent the sea water intrusion for this coastal area. Mathematical simulation of artificial recharge towards arresting the seawater intrusion for different scenarios gives a better understanding Table 4. Distributed quantity of water for recharging the Zones $A$ and $B$

\begin{tabular}{|c|c|c|c|}
\hline $\begin{array}{c}\text { Distance } \\
(\mathrm{km})\end{array}$ & $\begin{array}{c}\text { Good } \\
\left(\mathrm{M} \mathrm{m}^{3} \text { /year) }\right.\end{array}$ & $\begin{array}{c}\text { Moderate } \\
\left(\mathrm{M} \mathrm{m}^{3} / \text { year) }\right.\end{array}$ & $\begin{array}{c}\text { Poor } \\
\left(\mathrm{M} \mathrm{m}^{3} \text { /year) }\right.\end{array}$ \\
\hline \multicolumn{4}{|l|}{ Zone A } \\
\hline 7 & 7.06 & 4.94 & 2.12 \\
\hline 8 & 10.09 & 7.06 & 3.03 \\
\hline 9 & 15.13 & 10.59 & 4.54 \\
\hline 10 & 25.22 & 17.65 & 7.56 \\
\hline 11 & 55.47 & 38.83 & 16.64 \\
\hline 11.9 & 600.07 & 420.05 & 180.02 \\
\hline \multicolumn{4}{|l|}{ Zone B } \\
\hline 4 & 19.40 & 13.58 & 5.82 \\
\hline 5 & 30.30 & 21.21 & 9.09 \\
\hline 6 & 48.49 & 33.94 & 14.55 \\
\hline 7 & 84.85 & 59.40 & 25.46 \\
\hline 8 & 193.94 & 135.76 & 58.18 \\
\hline 8.9 & 2157.58 & 1510.30 & 647.27 \\
\hline
\end{tabular}

of the interface movement towards sea. But, a three dimensional numerical model with sufficient data can provide a powerful tool for coastal aquifers. This methodology can be systematically evaluated in any selected coastal area where the hydro-geological information is available.

Acknowledgements

We wish thank Dr.S.Sivamurthy Reddy and Dr.M.A.Sivasankaran Department of Civil Engineering, Pondicherry Engineering College, Pondicherry for the support and help in data collection. We thank The Director, Centre for Water 
Resources, Anna University, Chennai for providing computing facilities, support and encouragement.

\section{References}

1. Aller L, Bennett T, Lehr JH and Petty RJ (1987) DRASTIC: a standardized system for evaluating ground water pollution potential using hydrogeologic settings, U.S.EPA Report 600/2-87/035.

2. Benedict M. Mutua and Andreas Klik (2006) Estimating spatial sediment delivery ratio on a large rural catchment. J. Spatial Hydrol. 6(1) 64-80.

3. Chachadi AG and Lobo-Ferreira JP (2001) Sea water intrusion vulnerability mapping of aquifers using GALDIT method. Proc. Workshop on Modelling in Hydrogeology. Anna University, Chennai, 143-156.

4. Chachadi AG and Lobo-Ferreira JP (2005) Assessing aquifer vulnerability to sea-water intrusion using GALDIT method: Part 2 GALDIT Indicator Descriptions. IAHS and LNEC, Proc. The Fourth Inter Celtic Colloquium on Hydrology and Management of Water Resources. Universidade do Minho, Guimarães, Portugal.

5. Chachadi AG, Lobo-Ferreira JP, Noronha L and Choudri BS (2003) Assessing the impact of sea-level rise on sea water intrusion in coastal aquifers using GALDIT model. APRH/CEAS, Seminário Sobre Águas Subterrâneas, Lisboa.

6. Das SN, Narula KK and Raymond L (1992) Runoff potential indices of watersheds in Tilaiya catchment, Bihar, India through use of remote sensing and implementation of GIS. J. Indian Society of Remote Sensing. 20 (4) 207221.

7. Kulkarni AA, Aggarwal SP and Das KK (2004) Estimation of surface runoff using rainfallrunoff modeling of Warasgaon dam catchment. http://www.gisdevelopment.net.

8. Manivannan S, Ramaswamy $\mathrm{K}$ and Shanthi $\mathrm{R}$ (2001) Predicting runoff from tank catchments using green-Ampt and SCS runoff curve number models. Intnl. J. Agricultural Engineering. 10 (1\&2) pp. 57-69.

9. Mockus V (1972) Estimation of direct runoff from storm rainfall. In National Engineering Handbook. NEH Notice. 4-102, 10.1-10.22.

10. Nayak TR and Jaiswal RK (2003) RainfallRunoff modeling using satellite data and GIS for Bebas River in Madhya Pradesh. Institution of Engineers (I), 84, 47-50.

11. Phukon $P$, Phukan $S$, Das $P$ and Sarma B (2004) Multicriteria evaluation in GIS environment for ground water resource mapping in Guwahati City Areas, Assam. http://www.gisdevelopment.net.

12. Ramalingam $M$ and Santhakumar AR (1999) Case study on artificial recharge using Remote Sensing and GIS. http://www.gisdevelopment.net.

13. Raudkivi AJ and Callander RA (1976) Analysis of ground water flow. Edward Arnold (Publishers) Itd, Old Woking, Surrey, London.

14. Zade M. Ray SS, Dutta S and Panigrahy S (2005) Analysis of runoff pattern for all major basins of India derived using remote sensing data. Curr. Sci. 88 (8) 1301-1305.

15. Saraf AK and Choudhury PR (1998) Integrated Remote Sensing and GIS for ground water exploration and identification of artificial recharges sites. IntnI. J. Remote Sensing. 19 (10)1825-1841.

16. Shahid S and Nath SK (2000) GIS integration of remote sensing and electrical sounding data for hydrogeological exploration. J. Spatial Hydrol. 2 (1), 1-12.

17. Sikdar PK, Chakraborty S, Adhya E and Paul PK (2004) Land Use/Land cover changes and ground water potential zoning in and around Raniganj coal mining area, Bardhaman District, West Bengal-A GIS and Remote Sensing Approach. J. Spatial Hydrol. 4 (2)1-24.

18. Solaimani K, Mohammadi H, Ahmadi MZ and Habibnejad M (2005) Flood occurrence hazard forecasting based on geographical information system. Intnl. J. Environ. Sci. \& Technol. 2 (3) 253-258.

19. Stoertz MW and Bradbury KR (1989) Mapping recharge areas using a ground water flow model - A case study. J. Ground Water. 27(2), 220-226.

20. Toleti BVMR, Chaudhary BS, Kumar KEM and Saroha GP (2000) Integrated ground water resources mapping in Gurgaon District, India using remote sensing and GIS techniques. http://www.gisdevelopment.net

21. Todd DK (1980) Ground water Hydrology. John Wiley \& Sons, Singapore. 